\title{
Weed incidence and sowing time affect soybean development
}

\author{
Luciano Schievenin', Braulio Otomar Caron', Elvis Felipe Elli², \\ 'Federal University of Santa Maria, Brazil \\ 2University of Sao Paulo, Brazil \\ 3University of Passo Fundo, Brazi \\ *Corresponding author, e-mail: felipe_schwerz@hotmail.com
}

Felipe Schwerz², Ana Paula Rockenbach³, Diecson Ruy Orsolin da Silva ${ }^{1}$

\begin{abstract}
Despite the economic importance of the effects of weeds on the plastochron and emission of nodes of soybean plants, it has not been studied in detail. The aim of this study was to provide information about the effects of weeds on the development of soybean plants by determining the plastochron and number of nodes of soybean plants of different cultivars sown at different times in soils with presence and absence of weeds. A field study was conducted during the 2013/2014 crop season including a phytosociological survey to identify the occurring weeds, and the determination of the plastochron and final number of nodes of soybean plants. Four botanical families of weeds were found infesting the soybean crops. The plastochron and final number of nodes of soybean were influenced by the cultivar, sowing time, and presence of weeds. The plastochron was higher when the plants were grown in the presence weeds due to the higher relative frequency, relative density, relative abundance, and importance value index of the Euphorbia heterophyla, Ipomoea purpurea, and Urochloa plantaginea species, which resulted in a slower development of the soybean plants, and lower number of nodes per plant.
\end{abstract}

Keywords: Glycine max, interspecific competition, phytosociological survey, plastochron, thermal sum

\section{Introduction}

Soybean (Glycine max (L.) Merril) is one of the world's most important oilseed plant due to its high protein and oil contents (Yang et al., 2016) and its general use for human and animal consumption. In Brazil, 114.07 million Mg of soybeans were produced in the 2016/2017 crop season, and the estimate production for $2017 / 2018$ is 108.6 million Mg (Conab, 2017).

The yield of soybean plants is affected by several factors during its development; one of the main factor is its competition with weeds (Rezvani et al., 2013; Knezevic, 2014; Datta et al., 2017; Gharde et al., 2018). Prolonged interference of weeds in soybean production areas may result in significant yield and quality losses, which depend on the infestation degree, seed bank quality, climatic conditions, and cultural practices used, such as the sowing time (Silva et al., 2008; Matsuo et al., 2015; Zanon et al., 2015).

Weed management in crops depends on the weed species found in the crop, and their density and phenological stages (Korres, 2018). Therefore, phytosociological studies are needed to assess the weed populations in the area of interest. However, soybean crops are sensitive to weed interference, thus, an appropriate manage of weeds is necessary to the development of this crop (Ulloa et al., 2010; Datta et al., 2017).

The growth rate of soybean crops can 
be estimated by the speed of appearance of nodes in the main stem of the plants during their vegetative phase. The time interval between the appearance of nodes on the stem of dicot species is called plastochron, with units of ${ }^{\circ} \mathrm{C}$ day node-1 (Streck et al., 2005). According to Streck et al. (2008), the plastochron of soybean plants is dependent on the cultivar. Moreover, the final number of nodes is dependent on the cultivars, sowing time, and photoperiod, and is related to the duration of the crop cycle of the cultivar (Setiyono et al., 2007; Zanon et al., 2016).

Characterizing the development of soybean cultivars in different sowing times and under competition with weeds is important to improve the efficiency of the soybean production. However, the plastochron of some cultivars available in the market, and the weed interference in this variable is unknown due to the introduction of new cultivars that are adapted to the different edaphoclimatic regions.

Therefore, the aim of this study was to provide information about the effects of weeds on the development of soybean plants by determining the plastochron and number of nodes of soybean cultivars sown at different times in the presence or absence of weeds.

\section{Material and Methods}

A field study was conducted during the 2013/2014 crop season in Frederico Westphalen RS, Brazil $\left(27^{\circ} 23^{\prime} 48^{\prime \prime} S, 53^{\circ} 25^{\prime} 45^{\prime \prime} \mathrm{W}\right.$, and altitude of
$490 \mathrm{~m}$ ). The climate of the region is Cfa, subtropical humid, according to the Köppen classification, with an average annual temperature of $19.1^{\circ} \mathrm{C}$, varying from $0{ }^{\circ} \mathrm{C}$ to $38^{\circ} \mathrm{C}$ (Alvares et al., 2013).

The soil of the experimental area was classified as typical dystrophic Red Latosol (Oxisol) and its physicochemical analysis showed $\mathrm{pH}$ in water of $6.0,3.0 \mathrm{mg} \mathrm{dm}^{-3}$ of $\mathrm{P}$ (Mehlich), $160 \mathrm{mg} \mathrm{dm}^{-3}$ of $\mathrm{K}, 6.2 \mathrm{cmol}_{\mathrm{C}} \mathrm{dm}^{-3}$ of $\mathrm{Ca}, 3.3 \mathrm{cmol}_{\mathrm{c}}$ $\mathrm{dm}^{-3}$ of $\mathrm{Mg}, 0.0 \mathrm{cmol}_{\mathrm{c}} \mathrm{dm}^{-3}$ of $\mathrm{Al}, \mathrm{CEC}$ of $9.9 \mathrm{cmol}_{\mathrm{c}}$ $\mathrm{dm}^{-3}$; base saturation of $76 \%$, and $3.1 \%$ of organic matter. The soil was fertilized according to the soil analysis with $45 \mathrm{~kg} \mathrm{ha}^{-1}$ of potassium chloride and $85 \mathrm{~kg} \mathrm{ha}^{-1}$ of triple superphosphate at sowing.

The experiment was conducted in a randomized complete block design, in a $3 \times 5 \times 2$ factorial arrangement with three replicates, consisting of three sowing times (October 15, November 15, and December 15), five soybean cultivars (BMX-TornadoRR, BMX-AlvoRR, BMXVelozRR, TEC-7849IPRO, and TEC-5718IPRO), and two weed conditions (presence and absence of weeds).

All cultivars used are resistant to glyphosate herbicide (RR). The seeds used were from the Central Gaúcha cooperative, and Brasmax Genética company. These soybean cultivars were selected because they are recommended to the study region, have high yield potential, and present different maturation times and growth habits (Table 1).

Table 1. Characteristics of the soybean cultivars used in the experiment.

\begin{tabular}{lccc}
\hline \multicolumn{1}{c}{ Cultivar } & Maturation Group & Recomendation & Growth Habit \\
\hline BMX Tornado RR & 6.2 & RS, SC, PR, SP, MS & Indeterminate \\
BMX Alvo RR & 5.9 & RS, SC, PR, SP & Indeterminate \\
BMX Veloz RR & 5.0 & RS, SC, PR & Indeterminate \\
TEC 7849 IPRO & 7.8 & RS, SC, PR, SP, MS & Indeterminate \\
TEC 5718 IPRO & 5.7 & RS, SC, PR & Determinate \\
\hline
\end{tabular}

The experimental units consisted of five 3-meter rows spaced $45 \mathrm{~cm}$ apart, with central evaluation area of $4.5 \mathrm{~m}^{2}$. The weeds in the area were controlled with glyphosate herbicide at 15 days before sowing. The seeds were sowed manually using depths of $3 \mathrm{~cm}$ and density of 20 seed $\mathrm{m}^{-1}$. The seedling emergence was defined as the time that $50 \%$ of the seedlings were visible above the ground. The seedlings were thinned seven days after emergence, leaving
11 plants per meter to obtain a final density that represented 250,000 plants $\mathrm{ha}^{-1}$.

The weeds were quantified and identified at 42 days after the emergence of the soybean plants using the square inventory method, which consists in subjectively finding patterns within the community to be sampled, with sampling not favoring a certain pattern (Braun-Blanquet, 1979). A $0.5 \times 0.5 \mathrm{~m}$ frame $\left(0.25 \mathrm{~m}^{2}\right)$ was randomly launched twice, making a total sampling area of 
$0.50 \mathrm{~m}^{2}$ per plot.

The class, family, and genus of the weeds in the frame were identified and described. This identification and number of plants was used to calculate the phytosociological variables-relative density (RD\% $=100 \times$ density of the species $\div$ total density of all species), relative frequency (RF\% = $100 \times$ frequency of the species $\div$ total frequency of all species), relative abundance (RA\% $=100 \times$ abundance of the species $\div$ total abundance of all species), and importance value index (IVI = RF\% + RD\% + RA\%). Thus, the RF\%, RD\%, and RA\% showed the correlations of a species with the other species found in the area (Mueller-Dombois \& Ellenberg, 1974).

Four seedlings of the central row of each plot were marked with colored wires at five days after emergence, and their number of visible nodes (when the related leaf had unrolled the edges of at least one leaf limb) in the main stem was counted every two days (Johnson, 1997).

Air temperature and precipitation during the crop cycle were collected from a meteorological station of the Brazilian National Institute of Meteorology that is connected to the an agroclimatology laboratory at approximately $300 \mathrm{~m}$ from the experiment area.

The temperatures at sowing times varied, but they were above the base temperature of the crop $\left(10^{\circ} \mathrm{C}\right)$, and within its optimum temperature range $\left(20^{\circ} \mathrm{C}\right.$ to $33^{\circ} \mathrm{C}$ ) (Setiyono et al., 2007). The precipitation in the first two sowing times was higher than that in the third due to the low precipitation occurred in February (Figure 1).
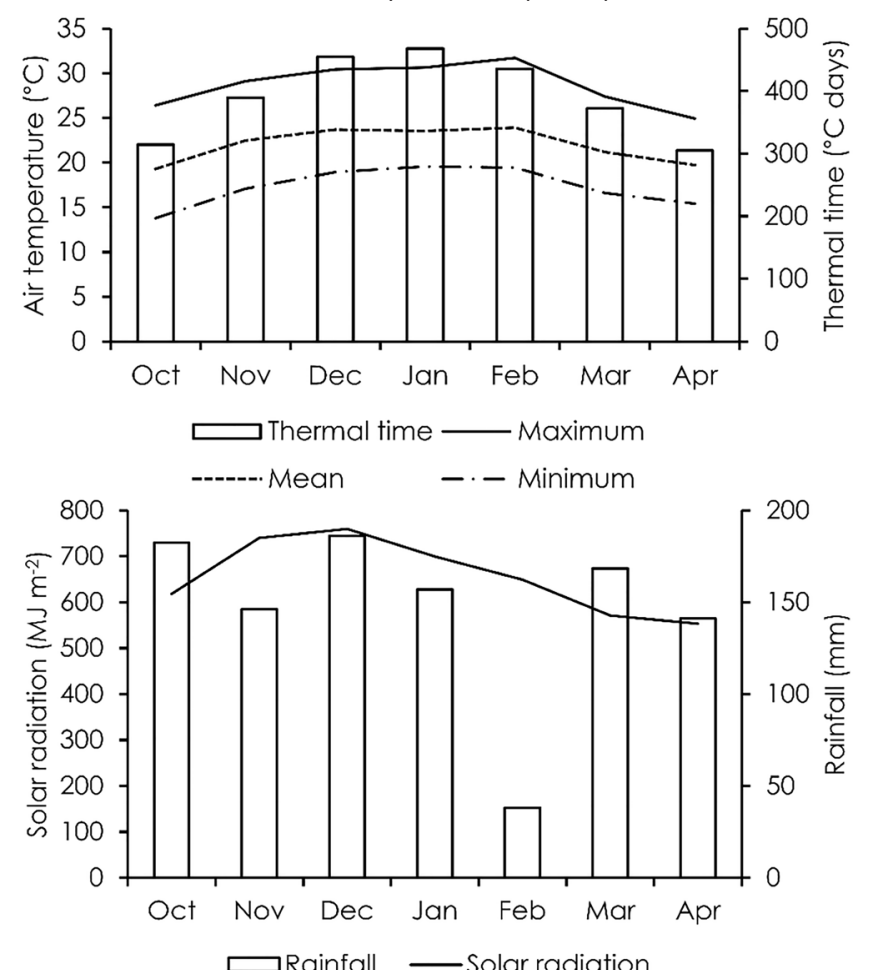

Figure 1. Air temperature, thermal sum, precipitation, and accumulated global solar radiation during the soybean crop cycle. Frederico Westphalen RS, Brazil, 2014.

The arithmetic means of the maximum and minimum air temperatures were used to obtain the average daily temperature (ADT). The daily thermal sum (DTS, ${ }^{\circ} \mathrm{C}$ day) was calculated from the emergency, considering the base temperature (BT) of the crop of $10^{\circ} \mathrm{C}$ (Piper et al., 1996), using the equation proposed by Gilmore \& Rogers (1958) (DTS = (ADT - BT) 1 day). The accumulated thermal sum (ATS, ${ }^{\circ} \mathrm{C}$ day) was the sum of the DTS, $(A T S=\Sigma D T S)$.

The marked plants were subjected to linear regression analysis considering the ATS, and number of nodes in their main stems. Thus, the plastochron was the inverse of the angular coefficient of the linear regression equation (XUE et al., 2004). At the end of the experiment, the final number of nodes in the main stem of the marked plants was evaluated.

The plastochron and final number of nodes were subjected to analysis of variance 
using the Genes program (Cruz, 2013) and the parameters that presented a significant difference at $5 \%$ probability of error were compared by the Tukey's test.

\section{Results and Discussions}

The phytosociological survey showed 385 weed plants infesting the soybean crops; they were from two Liliopsida, and three Magnoliopsida orders, and four botanical families (Table 2). Oliveira \& Freitas (2008) found similar results, with Poaceae and Asteraceae as the two main families of weeds existing in Brazil, which are found in areas with soybean, sunflower, and sugarcane crops.

The weeds found varied according to the soybean cultivars, with higher RF\% of Euphorbia heterophyla, and Urochloa plantaginea species with the BMX-AlvoRR cultivar, and Ipomoea purpurea, and Digitaria horizontalis with the TEC7849IPRO cultivar in the first sowing time. The highest RF\% of weeds in the second and third sowing times was found with the BMX-TornadoRR cultivar (Table 3).

Table 2. Phytosociological survey of weeds in soybean crop areas. Frederico Westphalen RS, Brazil, 2014.

\begin{tabular}{lccc}
\hline Common name & Scientific name & Family & Class \\
\hline Papuã & Urochloa plantaginea (L.) Hitch. & Poaceae & Liliopsida \\
Milhã & Digitaria horizontalis Willd. (Digho) & Poaceae & Liliopsida \\
Leiteiro & Euphorbia heterophylla (L.) & Euphorbiaceae & Magnoliopsida \\
Corriola & Ipomoea purpurea (L.) Roth & Convolvulaceae & Magnoliopsida \\
Picão preto & Bidens pilosa (L.) Hook & Asteraceae & Magnoliopsida \\
\hline
\end{tabular}

Table 3. Relative frequency (RF\%) and relative density (RD\%) of weeds as a function of sowing time of different soybean cultivars. Frederico Westphalen RS, Brazil, 2014.

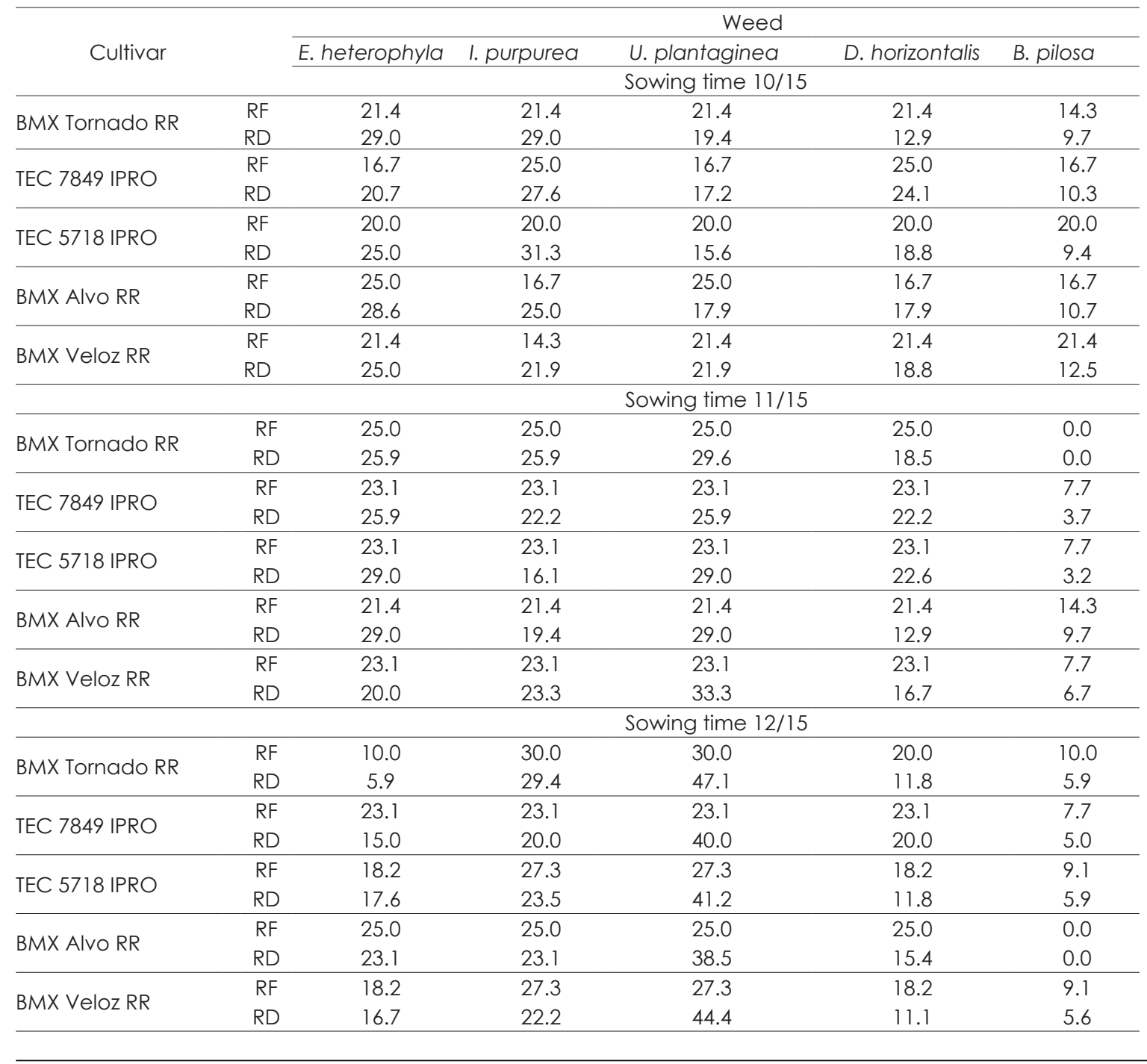


Silva et al. (2008) evaluated areas with low, medium, and high weed infestations in soybean crops and found similar species: I. purpurea, D. horizontalis, U. plantaginea, Euphorbia heterophyla, and Cyperus rotundus.

I. purpurea presented the highest RD\% (31.3\%), and Bidens pilosa presented the lowest RD\% (9.4\%) with the cultivar TEC-5718IPRO in the first sowing time (Table 3). However, in the second and third sowing time, $U$. plantaginea showed RD\% of $33.3 \%$ (BMX-VelozRR), and $47.1 \%$ (BMXTornadoRR).

Table 4. Relative abundance (RA\%) and importance value index (IVI) of weeds as a function of sowing time of different soybean cultivars. Frederico Westphalen RS, Brazil, 2014.

\begin{tabular}{|c|c|c|c|c|c|c|}
\hline \multirow{3}{*}{ Cultivar } & & \multicolumn{5}{|c|}{ Weed } \\
\hline & & E. heterophyla & I. purpurea & U. plantagine & D. horizontalis & B. Pilosa \\
\hline & & \multicolumn{5}{|c|}{ Sowing time $10 / 15$} \\
\hline \multirow{2}{*}{ BMX Tornado RR } & RA & 27.7 & 27.7 & 18.5 & 12.3 & 13.8 \\
\hline & $\mathrm{IVI}$ & 78.2 & 78.2 & 59.2 & 46.6 & 37.8 \\
\hline \multirow{2}{*}{ TEC 7849 IPRO } & RA & 25.0 & 22.2 & 20.8 & 19.4 & 12.5 \\
\hline & IVI & 62.4 & 74.8 & 54.7 & 68.6 & 39.5 \\
\hline \multirow{2}{*}{ TEC 5718 IPRO } & RA & 23.9 & 29.9 & 14.9 & 17.9 & 13.4 \\
\hline & IVI & 68.9 & 81.1 & 50.6 & 56.7 & 42.8 \\
\hline \multirow{2}{*}{ BMX Alvo RR } & RA & 22.5 & 29.6 & 21.1 & 14.1 & 12.7 \\
\hline & IVI & 76.1 & 71.2 & 64.0 & 48.6 & 40.1 \\
\hline \multirow{2}{*}{ BMX Veloz RR } & RA & 21.3 & 28.0 & 18.7 & 16.0 & 16.0 \\
\hline & IVI & 67.8 & 64.2 & 62.0 & 56.2 & 49.9 \\
\hline & & \multicolumn{5}{|c|}{ Sowing time $11 / 15$} \\
\hline \multirow{2}{*}{ BMX Tornado RR } & RA & 25.9 & 25.9 & 29.6 & 18.5 & 0.0 \\
\hline & IVI & 76.9 & 76.9 & 84.3 & 62.0 & 0.0 \\
\hline \multirow{2}{*}{ TEC 7849 IPRO } & RA & 32.3 & 18.5 & 21.5 & 18.5 & 9.2 \\
\hline & $\mathrm{IVI}$ & 81.3 & 63.8 & 70.5 & 63.8 & 20.6 \\
\hline \multirow{2}{*}{ TEC 5718 IPRO } & RA & 27.3 & 15.2 & 27.3 & 21.2 & 9.1 \\
\hline & $\mathrm{IVI}$ & 76.3 & 60.5 & 76.3 & 66.5 & 20.5 \\
\hline \multirow{2}{*}{ BMX Alvo RR } & RA & 25.4 & 25.4 & 25.4 & 11.3 & 12.7 \\
\hline & $\mathrm{IVI}$ & 75.8 & 63.1 & 75.8 & 55.3 & 30.2 \\
\hline \multirow{2}{*}{ BMX Veloz RR } & RA & 17.6 & 20.6 & 29.4 & 14.7 & 17.6 \\
\hline & $\mathrm{IVI}$ & 69.8 & 63.0 & 81.5 & 50.7 & 35.0 \\
\hline & & \multicolumn{5}{|c|}{ Sowing time $12 / 15$} \\
\hline \multirow{2}{*}{ BMX Tornado RR } & RA & 13.6 & 22.7 & 36.4 & 13.6 & 13.6 \\
\hline & IVI & 29.5 & 82.1 & 113.4 & 45.4 & 29.5 \\
\hline \multirow{2}{*}{ TEC 7849 IPRO } & RA & 19.1 & 17.0 & 34.0 & 17.0 & 12.8 \\
\hline & IVI & 57.2 & 60.1 & 97.1 & 60.1 & 25.5 \\
\hline \multirow{2}{*}{ TEC 5718 IPRO } & RA & 20.9 & 18.6 & 32.6 & 14.0 & 14.0 \\
\hline & $\mathrm{IVI}$ & 56.8 & 69.4 & 101.0 & 43.9 & 28.9 \\
\hline \multirow{2}{*}{ BMX Alvo RR } & RA & 23.1 & 23.1 & 38.5 & 15.4 & 0.0 \\
\hline & IVI & 71.2 & 71.2 & 101.9 & 55.8 & 0.0 \\
\hline \multirow{2}{*}{ BMX Veloz RR } & RA & 21.4 & 19.0 & 38.1 & 14.3 & 7.1 \\
\hline & IVI & 56.3 & 68.5 & 109.8 & 43.6 & 21.8 \\
\hline
\end{tabular}

E. heterophylla presented the highest RA\% (32.3\%) in the second sowing time for the TEC-7849IPRO cultivar. U. plantaginea was the most abundant species in all soybean cultivars in the third sowing time, with $10 \%$ to $15 \%$. This
According to Constantin et al. (2007), RD\% is the phytosociological parameter that better show the importance of a species in a given area; they found a weed community infesting soybean crops consisting mainly of $U$. plantaginea, E. heterophyla, and B. Pilosa, which have competitive potential with soybean plants.

1. purpurea presented the highest RA\% in the first sowing time, with similar distribution in the areas with the TEC-5718IPRO (29.9\%), and BMXAlvoRR (29.6\%) cultivars (Table 4). 
B. pilosa presented the lowest IVI for the cultivar BMX-TornadoRR in the first $(37.8 \%)$ and second sowing times (0\%) (Table 4). U. plantaginea presented the highest IVI for the BMX-TornadoRR (113.4\%), and BMX-VelozRR (109.8\%) cultivars in the third sowing time. Santi et al. (2014) found similar results when evaluating the phytosociological variability of weeds in soybean crops, with IVI of $51.92 \%$ for U. plantaginea.

Information on phytosociological parameters of weeds for different cultivars and sowing times is essential for planning a weed management program. Evaluating the presence of weeds and their populations during the crop cycle is important, especially at the critical period of control to prevent interference with the crop (Kamoshita et al., 2014; Pinke et al., 2016; Rauber et al., 2018).

The analysis of variance showed a significant difference in plastochron due to the interaction between cultivar, sowing time, and weed conditions. The highest plastochron $(73.86$ ${ }^{\circ} \mathrm{C}$ day node ${ }^{-1}$ ) (Table 5) was found in the first sowing time of the cultivar BMX-AlvoRR, in the presence of weeds. This can be related to the high RF\% (Table 3), and IVI (Table 4) of the E. heterophyla, and $U$. plantaginea species, which competed with this soybean cultivar.

Table 5. Effect of the interaction between cultivars, sowing times, and presence of weeds on the plastochron of soybean plants. Frederico Westphalen RS, Brazil, 2014.

\begin{tabular}{|c|c|c|c|c|c|c|c|}
\hline \multirow{2}{*}{ Cultivar } & \multirow{2}{*}{ Weed } & \multicolumn{6}{|c|}{ Sowing times } \\
\hline & & \multicolumn{2}{|c|}{$10 / 15$} & \multicolumn{2}{|c|}{$11 / 15$} & \multicolumn{2}{|c|}{$12 / 15$} \\
\hline \multirow{2}{*}{ BMX Tornado RR } & Presence & 67.47 & $\mathrm{bcCa}$ & 86.02 & a A a & 70.57 & $a B a$ \\
\hline & Absence & 65.01 & $b B \beta$ & 75.30 & $C A \beta$ & 66.29 & $b B \beta$ \\
\hline \multirow{2}{*}{ TEC 7849 IPRO } & Presence & 65.76 & $C B \beta$ & 85.08 & $a b A a$ & 61.71 & $\mathrm{~d} C \mathrm{a}$ \\
\hline & Absence & 70.43 & $a A a$ & 70.14 & $d A \beta$ & 61.56 & $c B a$ \\
\hline \multirow{2}{*}{ TEC 5718 IPRO } & Presence & 60.97 & $d C \beta$ & 86.41 & $\mathrm{aA} \mathrm{a}$ & 64.70 & $c B a$ \\
\hline & Absence & 65.85 & $b B a$ & 83.47 & $a A \beta$ & 61.22 & $C \subset \beta$ \\
\hline \multirow{2}{*}{ BMX Alvo RR } & Presence & 73.86 & $\mathrm{aB} a$ & 83.32 & $\mathrm{~b} A \mathrm{a}$ & 68.50 & $\mathrm{~b} C \mathrm{a}$ \\
\hline & Absence & 70.95 & $a B \beta$ & 78.50 & $b A \beta$ & 66.77 & $a b C a$ \\
\hline \multirow{2}{*}{ BMX Veloz RR } & Presence & 69.17 & $b B \beta$ & 75.44 & $\mathrm{CA}$ a & 65.60 & $C C \beta$ \\
\hline & Absence & 71.05 & $a A a$ & 70.42 & $d A \beta$ & 68.12 & $a B a$ \\
\hline
\end{tabular}

weeds for each cultivar and sowing time) are not different by the Tukey's test at $5 \%$ probability of error.

A high plastochron indicates that a greater accumulated thermal sum is required for the plant to emit the next node on the main stem. This explains the higher plastochron found in treatments with presence of weeds.

The highest plastochron in the second sowing time were found for the cultivars $\mathrm{BMX}$ TornadoRR $\left(86.02{ }^{\circ} \mathrm{C}\right.$ day node $\left.{ }^{-1}\right)$, TEC-7849IPRO $\left(85.08{ }^{\circ} \mathrm{C}\right.$ day node-1), and TEC-5718IPRO (86.41 ${ }^{\circ} \mathrm{C}$ day node ${ }^{-1}$ ), in the presence of weeds (Table 5). This result may be related to the greater competition between crop and weed plants, and favorable meteorological conditions, which promoted the development of weeds, resulting in greater competition for space and solar radiation, hindering the development of soybean plants and increasing their plastochron.

The highest plastochron in the third sowing time were found for the BMX-TornadoRR $\left(70.57^{\circ} \mathrm{C}\right.$ day node $\left.{ }^{-1}\right)$ cultivar, in the presence of weeds. This was probably due to the high
$\mathrm{RF} \%, \mathrm{RD} \%$, and IVI of the I. purpurea and U. plantaginea species. Moreover, the highest plastochron of soybean in third sowing time was due to a greater competition for natural resources, especially solar radiation. Procópio et al. (2004) evaluated physiological aspects of soybean crops in competition with weeds and found the weeds presenting greater efficiency in the use of light per unit area of leaf, and in the use of water, despite their lower biomass production and lower leaf emission than the crop.

The TEC-7849IPRO cultivar presented the lowest plastochron $\left(61.71{ }^{\circ} \mathrm{C}\right.$ day node $\left.{ }^{-1}\right)$ in the third sowing time, probably due to the genetic characteristics of this cultivar (late-maturing, and larger plant size), which are more suitable for sowing in winter crops. Generally, plants of larger sizes have greater competitive ability.

The competitive ability of the cultivars differed due to canopy characteristics of the crops. According to Drews et al. (2009), plants 
with high plant size and leaf area index, and rapid canopy formation frequently result in crops with high competitive ability. However, the different competitive ability of the cultivars may not be related to morphological characteristics that affect light interception but are specific to the cultivar (Paynter \& Hills, 2009).

The plastochron of the cultivars grown in the absence of weeds presented no significant differences, since the sowing time presented a greater effect than the weeds. This was probably because of the development conditions of the soybean plants; when they are grown in a weedfree environment, the cultivar factor, mainly the development cycle, has lower effect on the plastochron than other factors, such as sowing time, and meteorological conditions.

The plastochron of all cultivars in the second sowing time was higher in the presence of weeds (Table 5), probably due to the higher water availability and average temperatures during the period of node emission (Figure 1) that caused a greater competition due to the weed biomass increment.

The higher plastochron generated by the competition with weeds represent a lower development of the crop plants. According to
Silva et al. (2008), weeds affect, irreversibly, the development and growth of soybean crops by generating competition for resources, and shading on the canopy of the crop. Heldwein et al. (2010) evaluated the plastochron of common bean plants grown under protected environment conditions and found a higher plastochron with the lower solar radiation availability because the plants produced less photoassimilates than they needed for their maintenance.

According to Silva et al. (2008), decreases in growth and development of crops grown with weeds vary according to the crop plant size, duration of the competition period, edaphoclimatic conditions, and biomass produced by the weed community.

The number of nodes depended on the presence or absence of weeds. The TEC7849IPRO cultivar presented the highest number of nodes (23.67 nodes plant ${ }^{-1}$ ), and the TEC5718 IPRO cultivar presented the lowest ( 12 nodes plant $\left.^{-1}\right)$ when grown in the presence of weeds, considering the three sowing times (Table 6). The final number of nodes in the first sowing time was higher (24 nodes plant $^{-1}$ ) for the TEC-7849IPRO cultivar grown in the absence of weeds.

Table 6. Effect of the interaction between cultivars, sowing times, and presence of weeds on the final number of nodes (plant ${ }^{-1}$ nodes) of soybean plants. Frederico Westphalen RS, Brazil, 2014.

\begin{tabular}{|c|c|c|c|c|c|c|c|}
\hline \multirow{2}{*}{ Cultivar } & \multirow{2}{*}{ Weed } & \multicolumn{6}{|c|}{ Sowing times } \\
\hline & & \multicolumn{2}{|c|}{$10 / 15$} & \multicolumn{2}{|c|}{$11 / 15$} & \multirow[b]{2}{*}{14.50} & \multirow[b]{2}{*}{$b C \beta$} \\
\hline RMY Tornado PP & Presence & 19.00 & $b A a$ & 16.50 & $b B \beta$ & & \\
\hline BMX Iornado RK & Absence & 19.00 & $b A a$ & 16.83 & $b B a$ & 16.00 & $b \subset a$ \\
\hline \multirow{2}{*}{ TEC 7849 IPRO } & Presence & 23.67 & $a A \beta$ & 18.92 & $a B \beta$ & 18.42 & $a B \beta$ \\
\hline & Absence & 24.00 & a A a & 19.83 & $a B a$ & 18.58 & $a C a$ \\
\hline \multirow{2}{*}{ TEC 5718 IPRO } & Presence & 12.00 & $\mathrm{dAa}$ & 12.00 & $d A a$ & 12.00 & $d A a$ \\
\hline & Absence & 12.00 & e A a & 12.00 & $\subset A a$ & 12.00 & e A a \\
\hline \multirow{2}{*}{ BMX Alvo RR } & Presence & 17.67 & $C A a$ & 15.08 & $C B \beta$ & 13.00 & $C \subset \beta$ \\
\hline & Absence & 16.67 & $d A \beta$ & 16.92 & $b A a$ & 13.83 & $C B a$ \\
\hline \multirow{2}{*}{ BMX Veloz RR } & Presence & 17.50 & $C A \beta$ & 15.00 & $C B \beta$ & 12.75 & $C \subset \beta$ \\
\hline & Absence & 18.00 & $c A a$ & 17.00 & $b B a$ & 13.33 & $\mathrm{dCa}$ \\
\hline
\end{tabular}

The third sowing time caused a reduction in the final number of nodes in four cultivars; however, the final number of nodes of the TEC5718IPRO cultivar in all sowing times presented no difference due to its determined growth habit (Table 6). In the third sowing time, BMX-VelozRR presented the lowest number of nodes among the cultivars that had indeterminate growth habit, in the presence of weeds (Table 6), reducing 4.75 nodes plant ${ }^{-1}$ from the first to the last sowing time. Reductions in plastochron and final number of nodes due to the delay of the sowing time can be a response to the photoperiod and presence of weeds, which significantly affect the development rate and duration cycle of the crop. 
The sensitivity to photoperiod of soybean varies according to the cultivar; each cultivar needs a specific accumulated photothermal index for its vegetative and reproductive stages (Toledo et al., 2010). Late-maturing cultivars require a higher degree-day accumulation than early-maturing cultivars. Moreover, unfavorable temperatures (below $20^{\circ} \mathrm{C}$ or above $30{ }^{\circ} \mathrm{C}$ ), low availability of solar radiation, and short photoperiod (low thermal time) are the most common abiotic factors occurring in late sowing times and determine the growth and development of the crops (Zanon et al., 2015; Schwerz et al., 2016).

Similarly, Martins et al. (2011) found a reduction of 4.3 nodes plant ${ }^{-1}$ for the BRS247 cultivar by delaying the sowing from November 9 to January 28. Setiyono et al. (2007) found a decrease in the final number of nodes in 12 soybean cultivars by delaying sowing and attributed this result to the decreasing photoperiod in which the plants were grown. Thus, the higher the reduction in the final number of nodes, the greater the response of the cultivar to photoperiod.

The results found in this study can assist producers in choosing the appropriate sowing time, between October and November, and the cultivars to be used, since delaying the sowing, combined with the presence of weeds, reduced the development of the evaluated cultivars. This information may be useful to producers and assist them in planning the crops and defining management strategies for weed control.

\section{Conclusion}

The plastochron and final number of nodes of soybean were influenced by the cultivar, sowing time, and presence of weeds.

The plastochron was higher when the plants were grown in the presence weeds due to the higher relative frequency, relative density, relative abundance, and importance value index of the Euphorbia heterophyla, Ipomoea purpurea, and Urochloa plantaginea species, which resulted in a slower development of the soybean plants, and lower number of nodes per plant.

The soybean cultivars of undetermined growth habit (BMX-TornadoRR, BMX-AlvoRR, BMX-VelozRR and TEC-7849IPRO) presented lower final number of nodes when their sowing time was delayed, and when they were grown in the presence of weeds.

\section{References}

Agostinetto, D., Rigoli, R.P., Galon, L.; Moraes, P.V.D., Fontana, L.C. 2009. Competitividade relativa da soja em convivência com papuã (Brachiaria plantaginea). Scientia Agraria 10:185190.

Alvares, C.A., Stape, J.L., Sentelhas, P.C., Moraes, G., Leonardo, J., Sparrovek, G. 2013. Köppen's climate classification map for Brazil. Meteorologische Zeitschrift 22:711-728.

Braun-Blanquet, J. 1979. Fitossociologia: bases para el estudio de las comunidades vegetales. Madri: H. Blume. 820 p.

CONAB. Companhia Nacional de Abastecimento. Acompanhamento da Safra Brasileira de Grãos - 2017. Disponível em: http://www.conab.gov.br/OlalaCMS/uploads/ arquivos/16_12_22_12_08_27_boletim_graos_ dezembro_2016.pdf. <Acesso em: 19 fev. 2018>.

Constantin, J., Oliveira Júnior, R.S., Cavalieri, S.D., Arantes, J.G.Z. 2007. Estimativa do período que antecede a interferência de plantas daninhas na cultura da soja, var. Coodetec 202, por meio de testemunhas duplas. Planta Daninha 25:231237.

Cruz, C.D. 2013. GENES - a software package for analysis in experimental statistics and quantitative genetics. Acta Scientiarum Agronomy 35:271-276.

Datta, A., Ullah, H., Tursun, N., Pornprom, T., Knezevic, S.Z., Chauhan, B.S. 2017. Managing weeds using crop competition in soybean [Glycine max (L.) Merr.]. Crop Protection 95:6068.

Drews, S., Neuhoff, D., Köpke, U. 2009. Weed suppression ability of three winter wheat varieties at different row spacing under organic farming conditions. Weed Research Journal 49:526-533.

Gharde, Y., Singh, P.K., Dubey, R.P., Gupta, P.K. 2018. Assessment of yield and economic losses in agriculture due to weeds in India. Crop Protection 107:12-18.

Gilmore, E.C., Rogers, J.S. 1958. Heat units as a method of measuring maturity in corn. Agronomy Journal 50:611-615.

Heldwein, A.B., Streck, N.A., Sturza, V.S., Loose, L.H., Zanon, A.J., Toebe, M., Souza, A.T., Peters, M.B., Karlec, F. 2010. Plastocrono e rendimento 
de feijão-de-vagem cultivado sob ambiente protegido e no ambiente externo em semeadura tardia no outono. Ciência Rural 40:768-773.

Johnson, S. R. How a soybean plant develops. Ames: lowa Stale University of Science and Technology, and Cooperative Extension Service, 1997. 18p. Special Report n. 53.

Kamoshita, A., Araki, Y., Nguyen, Y.T. 2014. Weed biodiversity and rice production during the irrigation rehabilitation process in Cambodia. Agriculture, Ecosystems \& Environment 194:1-6.

Knezevic, S.Z. 2014. Integrated weed management in soybean. In: Recent Advances in Weed Management (pp. 223-237). Springer, New York, NY.

Korres, N.E. 2018. Agronomic Weed Control: A Trustworthy Approach for Sustainable Weed Management. In: Non-Chemical Weed Control. Springer, New York, NY, 97-114p.

Martins, J.D., Radons, S.Z., Streck, N.A., Knies, A.E., Carlesso, R. 2011. Plastocrono e número final de nós de cultivares de soja em função da época de semeadura. Ciência Rural 41:954-959.

Matsuo, N., Yamada, T., Hajika, M., Fukami, K., Tsuchiya, S. 2015. Planting date and row width effects on soybean production in Southwestern Japan. Agronomy Journal 107:415-424.

Müeller-Dombois, D., Ellenberg, H.A. 1974. Aims and methods of vegetation ecology. New York: John Wiley. 547 p.

Oliveira, A.R., Freitas, S.P. 2008. Levantamento fitossociológico de plantas daninhas em áreas de produção de cana-de-açúcar. Planta Daninha 26:33-46.

Paynter, B.H., Hills, A.L. 2009. Barley and rigid ryegrass (Lolium rigidum) competition is influenced by crop cultivar and density. Weed Technology Journal 23:40-48.

Pinke, G., Blazsek, K., Magyar, L., Nagy, K., Karácsony, P., Czúcz, B., Botta-Dukát, Z. 2016. Weed species composition of conventional soybean crops in Hungary is determined by environmental, cultural, weed management and site variables. Weed Research 56: 470-481.

Piper, E.L., Boote, K.J., Jones, J.W., Grimm, S.S. 1996. Comparison of two phenology models for predicting flowering and maturity date of soybean. Crop Science 36:1606-1614.

Procópio, S.O., Santos, J.B., Silva, A.A., Martinez, C.A., Werlang, R.C. 2004. Características fisiológicas das culturas de soja e feijão e de três espécies de plantas daninhas. Planta Daninha 22:211-216.
Rauber, R.B., Demaría, M.R., Jobbágy, E.G., Arroyo, D.N., Poggio, S. L. 2018. Weed Communities in Semiarid Rainfed Croplands of Central Argentina: Comparison between Corn (Zea mays) and Soybean (Glycine max) Crops. Weed Science 3:1-11.

Rezvani, M., Zaefarian, F., Jovieni, M. 2013. Weed suppression ability of six soybean [Glycine max (L.) MERR.] varieties under natural weed development conditions. Acta Agronomica Hungarica 61:43-53.

Santi, A.L., Bona, S.D., Lamego, F.P., Basso, C.J., Eitelwein, M.T., Cherubin, M.R., Gallon, M. 2014. Phytosociological variability of weeds in soybean field. Planta Daninha 32:39-49.

Schwerz, F., Caron, B.O., Elli, E.F., Souza, V.Q., Oliveira, D.M., Rockenbach, A.P. 2016. Soybean morphological and productive characteristics influenced by meteorological parameters and sowing dates. Científica 44:121-130.

Setiyono, T.D., Weiss, A., Specht, J., Bastidas, A.M., Cassman, K.G., Dobermann, A. 2007. Understanding and modeling the effect of temperature and daylength on soybean phenology under high-yield conditions. Field Crops Research 100:257-271.

Silva, A.F., Ferreira, E.A., Concenço, G., Ferreira, F.A., Aspiazu, I., Galon, L., Silva, A.A. 2008. Densidades de plantas daninhas e épocas de controle sobre os componentes de produção da soja. Planta Daninha 26:65-71.

Streck, N.A., Paula, G.M.D., Camera, C., Menezes, N.L.D., Lago, I. 2008. Estimating plastochron in soybean cultivars. Bragantia 67:67-73.

Streck, N.A., Tibola, T., Lago, I., Buriol, G.A., Heldwein, A.B., Schneider, F.M., Zago, V. 2005. Estimativa do plastocrono em meloeiro (Cucumis melo L.) cultivado em estufa plástica em diferentes épocas do ano. Ciência Rural 35:12751280.

Toledo, N.T., Muller, A.G., Berto, J.L., Mallmam, C.E.S. 2010. Ajuste do modelo fototérmico de estimativa do desenvolvimento e do índice de área foliar de soja. Revista Brasileira de Engenharia Agrícola e Ambiental 14:288-295.

Ulloa, S.M., Datta, A., Malidza, G., Leskovsek, R., Knezevic, S.Z. 2010. Yield and yield components of soybean [Glycine max (L.) Merr.] are influenced by the timing of broadcast flaming. Field Crops Research 119:348-354.

Zanon, A.J., Streck, N.A., Rocha, T.S.M.D., Alberto, C.M., Bartz, A.C., Paula, G. M.D., Tomiozzo, R., Costa, L.C., Fensterseifer, C.A., Tagliapietra, Cardoso, A.P., Weber, P.S., Bexaira, K.P. 2016. Growth habit effect on development of modern 
soybean cultivars after beginning of bloom in Rio Grande do Sul. Bragantia 75:445-458.

Zanon, A.J., Winck, J.E.M., Streck, N.A., Rocha, T.S.M., Cera, J.C., Richter, G.L., Lago, I., Santos, P.M., Maciel, R.L., Guedes, J.V.C., Marchesan, E. 2015. Desenvolvimento de cultivares de soja em função do grupo de maturação e tipo de crescimento em terras altas e terras baixas. Bragantia 74:400-411.

Xue, Q., Weiss, A., Baenziger, P.S. 2004. Predicting leaf appearance in field-grown winter wheat: evaluating linear and non-linear models. Ecological Modelling 175:261-270.

Yang, X.F., Yu, X.Q., Zhou, Z., Ma, W.J., Tang, G.X. 2016. A high-efficiency Agrobacterium tumefaciens mediated transformation system using cotyledonary node as explants in soybean (Glycine max L.). Acta Physiologiae Plantarum 38:1-10. 